\title{
Correction to: Feasibility study: one year fortnightly follow-up of the evolution of supra-spinatus degeneration via text- messages
}

Karl Vincent ${ }^{1,2^{*}}$, Olivier Gagey ${ }^{1}$ and Charlotte Leboeuf-Yde ${ }^{1,2,3}$

\section{Correction to: Chiropr Man Therap 28, 59 (2020) \\ https://doi.org/10.1186/s12998-020-00343-4}

Following publication of the original article [1], we were notified that the academic title has been mistakenly included as part of the second author's name.

The original article has been corrected.

\section{Author details}

'ED 566, Université Paris-Saclay, 15 r Georges Clemenceau, 91405 Paris, Orsay, France. ${ }^{2}$ Institut Franco-Européen de Chiropraxie, 24 Bd

Paul-Vaillant-Couturier, 94200, Toulouse, Ivry-sur-Seine, France. ${ }^{3}$ Institute for Regional Health Research, B.Winsløws, Vej 19, Dk, 5000 Odense C, Denmark.

Published online: 19 November 2020

\section{Reference}

1. Vincent $\mathrm{K}$, et al. Feasibility study: one year fortnightly follow-up of the

evolution of supra-spinatus degeneration via text-messages. Chiropr Man Therap. 2020;28:59. https://doi.org/10.1186/s12998-020-00343-4.

The original article can be found online at https://doi.org/10.1186/s12998020-00343-4.

* Correspondence: Vincentkarl347@gmail.com

'ED 566, Université Paris-Saclay, 15 r Georges Clemenceau, 91405 Paris, Orsay, France

${ }^{2}$ Institut Franco-Européen de Chiropraxie, 24 Bd Paul-Vaillant-Couturier, 94200, Toulouse, Ivry-sur-Seine, France

Full list of author information is available at the end of the article

(c) The Author(s). 2020 Open Access This article is licensed under a Creative Commons Attribution 4.0 International License, which permits use, sharing, adaptation, distribution and reproduction in any medium or format, as long as you give appropriate credit to the original author(s) and the source, provide a link to the Creative Commons licence, and indicate if changes were made. The images or other third party material in this article are included in the article's Creative Commons licence, unless indicated otherwise in a credit line to the material. If material is not included in the article's Creative Commons licence and your intended use is not permitted by statutory regulation or exceeds the permitted use, you will need to obtain permission directly from the copyright holder. To view a copy of this licence, visit http://creativecommons.org/licenses/by/4.0/ The Creative Commons Public Domain Dedication waiver (http://creativecommons.org/publicdomain/zero/1.0/) applies to the data made available in this article, unless otherwise stated in a credit line to the data. 